Supporting Information

Synthesis and Solid-State Polymerization of 5-(Pyren-1-yl)penta-2,4-diyn-1-ol Derivatives with an $N$-Phenylurethane or $N$-Benzylurethane Group

\author{
Shuhei Oshimizu, ${ }^{1}$ Shoko Takeshi, ${ }^{2}$ Tsubasa Sato, ${ }^{2}$ Ryohei Yamakado, ${ }^{1,2}$ \\ Yoko Tatewaki, ${ }^{3}$ and Shuji Okada ${ }^{1,2}$ \\ ${ }^{1}$ Graduate School of Organic Materials Science, Yamagata University, \\ 4-3-16 Jonan, Yonezawa 992-8510, Japan \\ ${ }^{2}$ Faculty of Engineering, Yamagata University, \\ 4-3-16 Jonan, Yonezawa 992-8510, Japan
}

${ }^{3}$ Division of Applied Chemistry, Tokyo University of Agriculture and Technology, 2-24-16 Naka-cho, Koganei 184-8588, Japan

Table of Contents

1. Fluorescence spectra S2

2. Synthesis of phenyl isocyanates S4

3. Synthesis of benzyl isocyanates S10 


\section{Fluorescence spectra}

Fluorescence spectra were measured using a Jasco FP-6100 spectrofluorophotometer. Figure S1 shows fluorescence spectra of 5-(1-pyrenyl)pent-2,4-butadiynyl carbamate derivatives in the powder form. All samples measured showed broad emission between
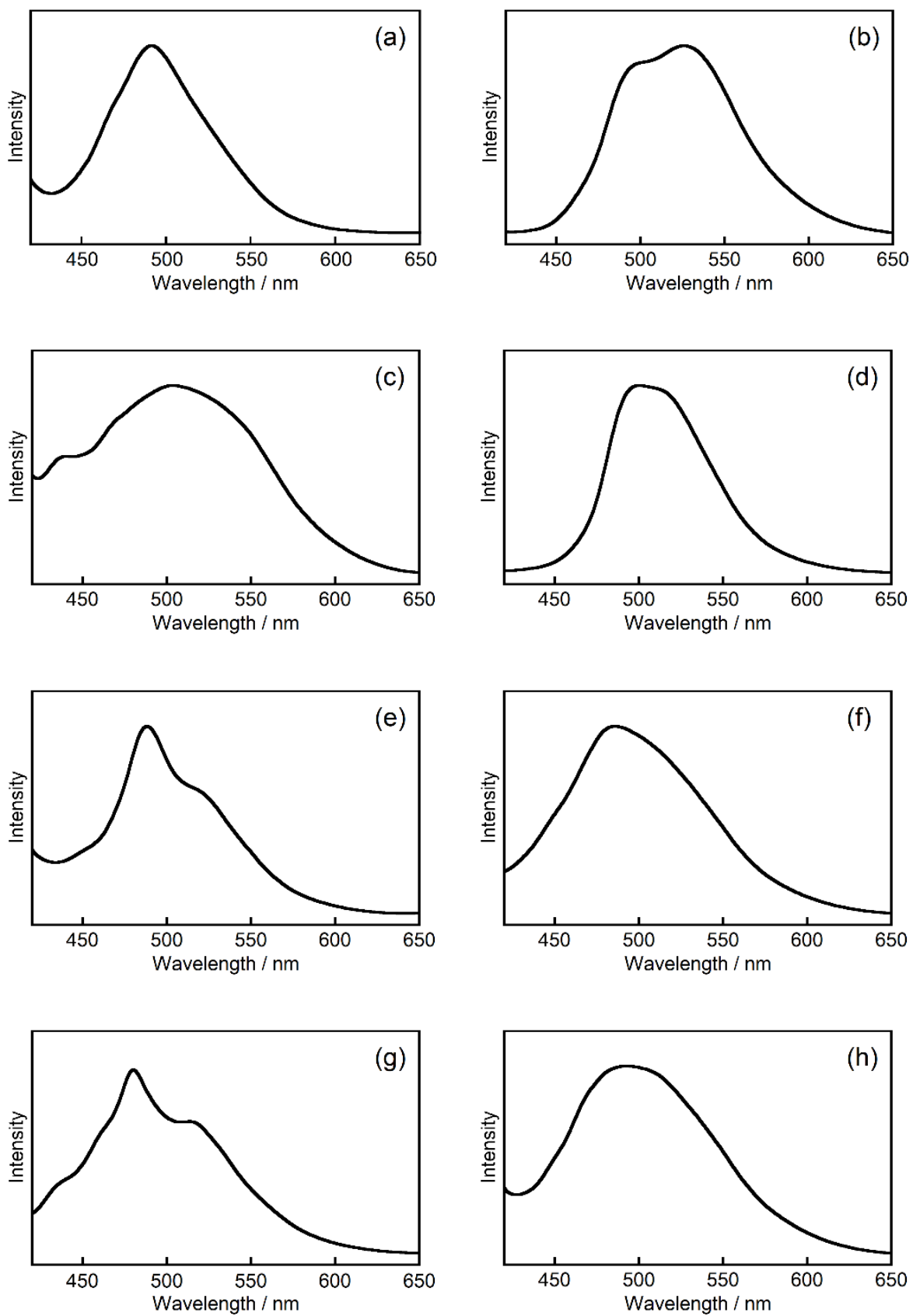

Figure S1 Fluorescence spectra of powders: (a) $\mathbf{H}-\mathbf{0}$, (b) $\mathbf{H}-\mathbf{1}$, (c) $\mathbf{C}_{\mathbf{1}} \mathbf{O}-\mathbf{0}$, (d) $\mathbf{C} \mathbf{1} \mathbf{O}-\mathbf{1}$, (e) $\mathbf{C}_{8} \mathbf{O}-\mathbf{0}$, (f) $\mathbf{C}_{\mathbf{8}} \mathbf{O}-\mathbf{1}$, (g) $\mathbf{C}_{\mathbf{1 2}} \mathbf{O}-\mathbf{0}$, and (h) $\mathbf{C}_{\mathbf{1 2}} \mathbf{O}-\mathbf{1}$. The excitation wavelength was $370 \mathrm{~nm}$. 
approximately 450 and $600 \mathrm{~nm}$. Since emission from the isolated molecules in solution showed the peaks at 397 and $417 \mathrm{~nm}$ as shown in Figure S2, the broad emission at longer wavelengths for the powder samples can be attributed to the excimer formation. ${ }^{\mathrm{S} 1}$ This fact indicates that two or more pyrene moieties are nearby in the solid state of these compounds. Spectral shapes, which were different among the compounds, seemed to contain information on the distance and geometry of two pyrene moieties.

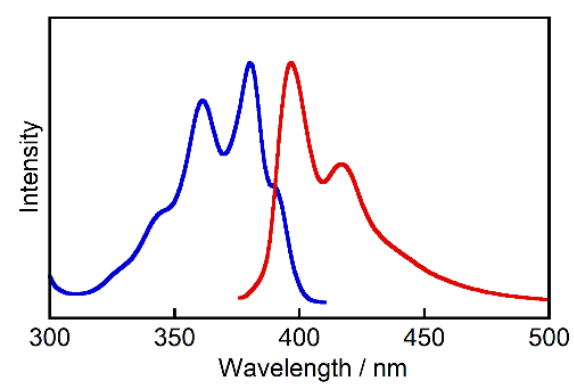

Figure S2 Fluorescence and excitation spectra of $\mathbf{H}-\mathbf{0}$. The sample was $2 \mu \mathrm{mol} / \mathrm{L}$ chloroform solution. The red line is the fluorescence spectra obtained at the excitation wavelength of $370 \mathrm{~nm}$. The blue line is the excitation spectra in which the emission at $397 \mathrm{~nm}$ was monitored.

\section{Reference}

(S1) Winnik, F. M. Photophysics of Preassociated Pyrenes in Aqueous Polymer Solutions and in Other Organized Media. Chem. Rev. 1993, 93, 587-614. 
2. Synthesis of phenyl isocyanates

Phenyl isocyanates $\mathbf{9 a}-\mathbf{d}$ to synthesize the corresponding urethane derivatives of 5 (pyren-1-yl)penta-2,4-diyn-1-ol $\mathbf{4}$ were prepared from methyl gallate $\mathbf{5}$ according to Figure S3. ${ }^{\mathrm{S} 2}$ Details of the synthesis procedures are described below.

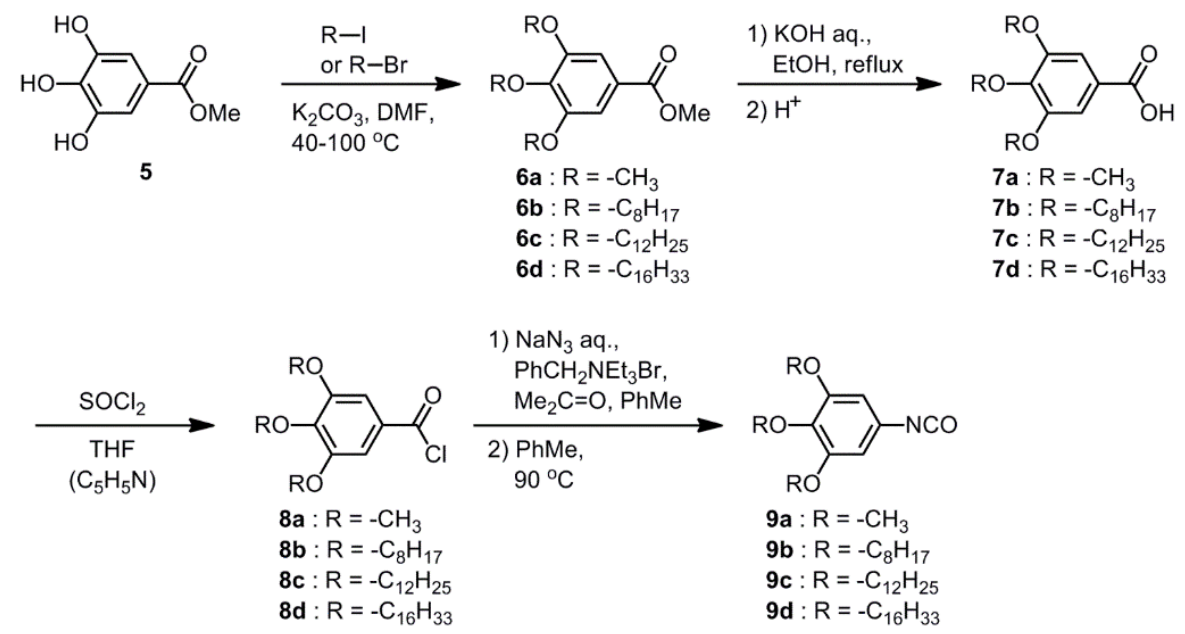

Figure S3 Synthesis scheme of $N$-phenyl isocyanate derivatives

Methyl 3,4,5-trimethoxybenzoate 6a. A mixture of methyl gallate 5 (5.00 g, 27.2 $\mathrm{mmol})$, iodomethane $(33.4 \mathrm{~g}, 235 \mathrm{mmol})$, and potassium carbonate $(32.6 \mathrm{~g}, 235 \mathrm{mmol})$ in DMF $(50 \mathrm{~mL})$ was stirred at $40{ }^{\circ} \mathrm{C}$ for $14 \mathrm{~h}$. Chloroform was added to the mixture and this solution was washed with water. The organic layer was dried over anhydrous sodium sulfate. After filtration, the solvent in the filtrate was removed under reduced pressure. The residue was recrystallized from chloroform-methanol mixture to afford $\mathbf{6 a}(4.80 \mathrm{~g}$ $21.2 \mathrm{mmol}, 78 \%$ ) as a colorless solid: IR (KBr) 2952, 2839, 1716, 1591, 1414, 1338, 1228, $11321038,1004,993,865,761,737 \mathrm{~cm}^{-1} ;{ }^{1} \mathrm{H}$ NMR (600 MHz, $\left.\mathrm{CDCl}_{3}\right) \delta 3.91(12 \mathrm{H}, \mathrm{s})$, $7.30(2 \mathrm{H}, \mathrm{s}) ;{ }^{13} \mathrm{C} \mathrm{NMR}\left(150 \mathrm{MHz}, \mathrm{CDCl}_{3}\right) \delta 51.87,55.89,60.55,106.48,124.86,141.86$, $152.64,166.32$.

3,4,5-Trimethoxybenzoic acid 7a. To a solution of $\mathbf{6 a}(3.00 \mathrm{~g}, 13.3 \mathrm{mmol})$ in ethanol $(100 \mathrm{~mL})$, potassium hydroxide $(1.64 \mathrm{~g}, 29.3 \mathrm{mmol})$ in water $(5 \mathrm{~mL})$ was added, and the mixture was refluxed for $7 \mathrm{~h}$. After solvent evaporation, $2 \mathrm{~mol} / \mathrm{L} \mathrm{HCl}$ aqueous solution $(50 \mathrm{~mL})$ was added and the mixture was extracted with diethyl ether. The combined organic layer was dried over anhydrous sodium sulfate. After filtration, the solvent in the filtrate was removed under reduced pressure to give $7 \mathrm{a}(1.67 \mathrm{~g}, 7.87 \mathrm{mmol}, 59 \%)$ as a colorless solid: IR (KBr) 2946, 2837, 1687, 1587, 1506, 1468, 1417, 1327, 1269, 1225 , $1182,1124,1001,939,858,762,715 \mathrm{~cm}^{-1} ;{ }^{1} \mathrm{H} \mathrm{NMR}\left(600 \mathrm{MHz}, \mathrm{CDCl}_{3}\right) \delta 3.93(6 \mathrm{H}, \mathrm{s})$, 
$3.94(3 \mathrm{H}, \mathrm{s}), 7.39(2 \mathrm{H}, \mathrm{s})$, a carboxyl proton was not clearly detected; ${ }^{13} \mathrm{C}$ NMR (150 $\left.\mathrm{MHz}, \mathrm{CDCl}_{3}\right) \delta 56.18,60.90,107.35,124.07,142.92,152.90,171.87$.

3,4,5-Trimethoxybenzoyl chloride 8a. A mixture of $7 \mathbf{a}(1.67 \mathrm{~g}, 7.87 \mathrm{mmol})$ and thionyl chloride $(2.84 \mathrm{~mL}, 39.4 \mathrm{mmol})$ in anhydrous THF $(30 \mathrm{~mL})$ was stirred at ambient temperature for $1 \mathrm{~h}$. THF and thionyl chloride remained in the mixture was removed by distillation under reduced pressure to give crude product including $8 \mathbf{a}(1.81 \mathrm{~g})$ as a pale orange solid: ${ }^{1} \mathrm{H} \mathrm{NMR}\left(600 \mathrm{MHz}, \mathrm{CDCl}_{3}\right) \delta 3.93(6 \mathrm{H}, \mathrm{s}), 3.97(3 \mathrm{H}, \mathrm{s}), 7.38(2 \mathrm{H}, \mathrm{s}) ;{ }^{13} \mathrm{C}$ NMR $\left(150 \mathrm{MHz}, \mathrm{CDCl}_{3}\right) \delta 56.35,60.93,108.87,127.68,144.51,152.94,167.59$. Compound $\mathbf{8} \mathbf{a}$ was used for synthesis of $\mathbf{9 a}$ without further purification.

3,4,5-Trimethoxyphenyl isocyanate 9a. Sodium azide (1.53 g, $23.6 \mathrm{mmol})$ and benzyltriethylammonium chloride $(2.69 \mathrm{~g}, 11.8 \mathrm{mmol})$ were dissolved in water $(2 \mathrm{~mL})$ and the solution was cooled using an ice bath. To this solution, crude compound $\mathbf{8 a}(1.81$ $\mathrm{g})$ in the mixture of acetone $(9 \mathrm{~mL})$ and toluene $(6 \mathrm{~mL})$ was added dropwise at the temperature controlled between 10 and $15{ }^{\circ} \mathrm{C}$. After addition completion, the mixture was stirred between 10 and $15^{\circ} \mathrm{C}$ for $3 \mathrm{~h}$ and extracted with toluene. The combined organic layer was dried over anhydrous sodium sulfate. After filtration, the filtrate was heated at $90{ }^{\circ} \mathrm{C}$ for $1 \mathrm{~h}$, and the solvent of the solution was removed under reduced pressure to give crude product including 9a (1.64 g) as a pale orange solid: ${ }^{1} \mathrm{H}$ NMR $\left(600 \mathrm{MHz}, \mathrm{CDCl}_{3}\right)$ $\delta 3.82(3 \mathrm{H}, \mathrm{s}), 3.84(6 \mathrm{H}, \mathrm{s}), 6.32(2 \mathrm{H}, \mathrm{s}) ;{ }^{13} \mathrm{C} \mathrm{NMR}\left(150 \mathrm{MHz}, \mathrm{CDCl}_{3}\right) \delta 56.15,60.94$, $102.15,124.44,128.98,136.08,153.60$. Compound $\mathbf{9 a}$ was used for synthesis of $\mathbf{C}_{1} \mathbf{O}-\mathbf{0}$ without further purification.

Methyl 3,4,5-trioctyloxybenzoate 6b. A mixture of methyl gallate 5 (5.00 g, 27.2 $\mathrm{mmol})$, 1-bromooctane $(21.1 \mathrm{~g}, 109 \mathrm{mmol})$, and potassium carbonate $(16.2 \mathrm{~g}, 177 \mathrm{mmol})$ in DMF $(50 \mathrm{~mL})$ was stirred at $100^{\circ} \mathrm{C}$ for $18 \mathrm{~h}$. Chloroform was added to the mixture and this solution was washed with water. The organic layer was dried over anhydrous sodium sulfate. After filtration, the solvent in the filtrate was removed under reduced pressure. The residue was purified by column chromatography (silica gel, chloroform) to give $\mathbf{6 b}$ (11.8 g, $22.7 \mathrm{mmol}, 83 \%$ ) as a pale orange liquid: IR (film) 2925, 2856, 1722, 1587, 1500, $1468,1433,1336,1219,1113,1016,958,862,766 \mathrm{~cm}^{-1} ;{ }^{1} \mathrm{H} \mathrm{NMR}\left(600 \mathrm{MHz}, \mathrm{CDCl}_{3}\right) \delta$ $0.89(9 \mathrm{H}, \mathrm{t}, J=6.5 \mathrm{~Hz}), 1.23-1.39(24 \mathrm{H}, \mathrm{m}), 1.44-1.51(6 \mathrm{H}, \mathrm{m}), 1.75(2 \mathrm{H}, \mathrm{tt}, J=7.1 \mathrm{~Hz}$, $7.1 \mathrm{~Hz}), 1.81(4 \mathrm{H}, \mathrm{tt}, J=7.1 \mathrm{~Hz}, 7.1 \mathrm{~Hz}), 3.88(3 \mathrm{H}, \mathrm{s}), 3.98-4.04(6 \mathrm{H}, \mathrm{m}), 7.26(2 \mathrm{H}, \mathrm{s})$; ${ }^{13} \mathrm{C} \mathrm{NMR}\left(150 \mathrm{MHz}, \mathrm{CDCl}_{3}\right) \delta 14.04,22.63,26.01,29.24 *, 29.30 *, 29.32 *, 29.46 *, 30.29$, $31.78,31.86,52.02,69.08,73.41,107.89,124.60,142.29,152.77,166.87$. Asterisks indicate overlapped peaks.

$3,4,5$-Trioctyloxybenzoic acid $\mathbf{7 b}$. To a solution of $\mathbf{6 b}(5.00 \mathrm{~g}, 9.60 \mathrm{mmol})$ in ethanol $(50 \mathrm{~mL})$, potassium hydroxide $(1.18 \mathrm{~g}, 21.1 \mathrm{mmol})$ in water $(5 \mathrm{~mL})$ was added, and the 
mixture was refluxed for $20 \mathrm{~h}$. After solvent evaporation, $2 \mathrm{~mol} / \mathrm{L} \mathrm{HCl}$ aqueous solution $(50 \mathrm{~mL})$ was added and the mixture was extracted with diethyl ether. The combined organic layer was dried over anhydrous sodium sulfate. After filtration, the solvent in the filtrate was removed under reduced pressure to give $7 \mathrm{~b}(3.10 \mathrm{~g}, 6.12 \mathrm{mmol}, 64 \%)$ as a colorless solid: IR (KBr) 2929, 2854, 1685, 1585, 1560, 1468, 1429, 1376, 1328, 1225 , $1113,954,868,773 \mathrm{~cm}^{-1}$; ${ }^{1} \mathrm{H} \mathrm{NMR}\left(600 \mathrm{MHz}, \mathrm{CDCl}_{3}\right) \delta 0.88(9 \mathrm{H}, \mathrm{t}, J=6.9 \mathrm{~Hz}) 1.20$ $1.38(24 \mathrm{H}, \mathrm{m}), 1.39-1.51(6 \mathrm{H}, \mathrm{m}), 1.68-1.83(6 \mathrm{H}, \mathrm{m}), 3.86-4.05(6 \mathrm{H}, \mathrm{m}), 7.26(2 \mathrm{H}, \mathrm{s}) \mathrm{a}$ carboxyl proton was not clearly detected; $\left.{ }^{13} \mathrm{C} \mathrm{NMR} \mathrm{(150} \mathrm{MHz,} \mathrm{CDCl}_{3}\right) \delta 14.06,22.65$, 26.03, 26.11, 29.30*, 29.37*, 29.39*, 29.52*, 30.33, 31.84*, 31.88*, 69.01, 73.43, 108.33, $124.25,142.77,152.71,172.30$. Asterisks indicate overlapped peaks.

3,4,5-Trioctyloxybenzoyl chloride 8b. A mixture of 7b $(0.608 \mathrm{~g}, 1.20 \mathrm{mmol})$ and thionyl chloride $(0.259 \mathrm{~mL}, 3.60 \mathrm{mmol})$ in anhydrous THF $(15 \mathrm{~mL})$ was stirred at ambient temperature for $1 \mathrm{~h}$. THF and thionyl chloride remained in the mixture was removed by distillation under reduced pressure to give crude product including $\mathbf{8 b}(0.700 \mathrm{~g})$ as a pale orange solid: ${ }^{1} \mathrm{H}$ NMR $\left(600 \mathrm{MHz}, \mathrm{CDCl}_{3}\right) \delta 0.89(9 \mathrm{H}, \mathrm{t}, J=6.5 \mathrm{~Hz}), 1.29-1.36(24 \mathrm{H}, \mathrm{m})$, $1.43-1.50(6 \mathrm{H}, \mathrm{m}), 1.73-1.68(6 \mathrm{H}, \mathrm{m}), 4.00-4.11(6 \mathrm{H}, \mathrm{m}), 7.33(2 \mathrm{H}, \mathrm{s}) ;{ }^{13} \mathrm{C} \mathrm{NMR}(150$ $\left.\mathrm{MHz} \mathrm{CDCl}_{3}\right) \delta 14.04,22.63,25.93 *, 26.00^{*}, 26.03^{*}, 29.16^{*}, 29.22^{*}, 29.25^{*}, 29.28^{*}$, $29.31^{*}, 29.41^{*}, 29.46^{*}, 30.28,31.77^{*}, 31.78^{*}, 31.84^{*}, 31.86^{*}, 69.26,73.65,109.88$, $127.22,144.64,152.79,167.59$. Asterisks indicate overlapped peaks. Compound $\mathbf{8 b}$ was used for synthesis of $\mathbf{9 b}$ without further purification.

3,4,5-Trioctyloxyphenyl isocyanate 9 b. Sodium azide $(0.259 \mathrm{~g}, 3.99 \mathrm{mmol})$ and benzyltriethylammonium chloride $(0.456 \mathrm{~g}, 2.00 \mathrm{mmol})$ were dissolved in water $(2 \mathrm{~mL})$ and the solution was cooled using an ice bath. To this solution, crude compound $\mathbf{8 b}(0.700$ $\mathrm{g})$ in the mixture of acetone $(6 \mathrm{~mL})$ and toluene $(3 \mathrm{~mL})$ was added dropwise at the temperature controlled between 10 and $15^{\circ} \mathrm{C}$. After addition completion, the mixture was stirred for $3 \mathrm{~h}$ and extracted with toluene. The combined organic layer was dried over anhydrous sodium sulfate. After filtration, the filtrate was heated at $90{ }^{\circ} \mathrm{C}$ for $1 \mathrm{~h}$, and the solvent of the solution was removed under reduced pressure to give crude product including $9 \mathrm{~b}(0.620 \mathrm{~g})$ as a pale orange solid: ${ }^{1} \mathrm{H} \mathrm{NMR}\left(600 \mathrm{MHz}, \mathrm{CDCl}_{3}\right) \delta 0.89(9 \mathrm{H}, \mathrm{t}$, $6.6 \mathrm{~Hz}), 1.26-1.37(24 \mathrm{H}, \mathrm{m}), 1.43-1.49(6 \mathrm{H}, \mathrm{m}), 1.72-1.83(6 \mathrm{H}, \mathrm{m}), 3.88-3.93(6 \mathrm{H}, \mathrm{m})$, $6.27(2 \mathrm{H}, \mathrm{s}) ;{ }^{13} \mathrm{C} \mathrm{NMR}\left(150 \mathrm{MHz}, \mathrm{CDCl}_{3}\right) \delta 14.03,22.63,26.00^{*}, 26.04 *, 26.09^{*}, 29.20 *$, $29.23 *, 29.29 *, 29.33 *, 29.46^{*}, 29.49^{*}, 30.21 *, 30.29,31.78,31.85,69.07,73.49,103.31$, $124.32,128.38,136.11,153.42$. Asterisks indicate overlapped peaks. Compound $\mathbf{9 b}$ was used for synthesis of $\mathbf{C}_{8} \mathbf{O}-\mathbf{0}$ without further purification.

Methyl 3,4,5-tridodecyloxybenzoate 6c. A mixture of methyl gallate 5 (10.0 g, 54.3 mmol), 1-bromododecane (58.6 g, $235 \mathrm{mmol})$, and potassium carbonate (32.6 g, 235 
mmol) in DMF (50 mL) was stirred at $100{ }^{\circ} \mathrm{C}$ for $30 \mathrm{~h}$. Chloroform was added to the mixture and this solution was washed with water. The organic layer was dried over anhydrous sodium sulfate. After filtration, the solvent in the filtrate was removed under reduced pressure. The residue was recrystallized from chloroform-methanol mixture to afford 6c (36.1 g $52.4 \mathrm{mmol}, 97 \%)$ as a colorless solid: IR (KBr) 2920, 2848, 1716, 1589, $1504,1468,1435,1336,1221,1132,1095,1012,962,862,762,721 \mathrm{~cm}^{-1} ;{ }^{1} \mathrm{H}$ NMR (400 $\left.\mathrm{MHz}, \mathrm{CDCl}_{3}\right) \delta 0.88(9 \mathrm{H}, \mathrm{t}, 6.7 \mathrm{~Hz}), 1.18-1.41(48 \mathrm{H}, \mathrm{m}), 1.43-1.53(6 \mathrm{H}, \mathrm{m}), 1.71-1.85$ $(6 \mathrm{H}, \mathrm{m}), 3.88(3 \mathrm{H}, \mathrm{s}), 3.99-4.04(6 \mathrm{H}, \mathrm{m}), 7.27(2 \mathrm{H}, \mathrm{s}) ;{ }^{13} \mathrm{C} \mathrm{NMR}\left(100 \mathrm{MHz}, \mathrm{CDCl}_{3}\right) \delta$ $14.04,22.64,26.03,29.23 *, 29.34 *, 29.52 *, 29.59 *, 29.62 *, 29.66 *, 30.88,51.99,69.00$, $73.38,107.78,124.56,142.17,152.71,166.83$. Asterisks indicate overlapped peaks.

3,4,5-Tridodecyloxybenzoic acid 7c. To a solution of $6 \mathrm{c}(5.00 \mathrm{~g}, 7.26 \mathrm{mmol})$ in ethanol $(50 \mathrm{~mL})$, potassium hydroxide $(0.898 \mathrm{~g}, 16.0 \mathrm{mmol})$ in water $(5 \mathrm{~mL})$ was added, and the mixture was refluxed for $3 \mathrm{~h}$. After solvent evaporation, $2 \mathrm{~mol} / \mathrm{L} \mathrm{HCl}$ aqueous solution $(50 \mathrm{~mL})$ was added and the mixture was extracted with diethyl ether. The combined organic layer was dried over anhydrous sodium sulfate. After filtration, the solvent in the filtrate was removed under reduced pressure to give 7c $(3.90 \mathrm{~g}, 5.78 \mathrm{mmol}$, $80 \%$ ) as a colorless solid: IR (KBr) 3382, 2920, 2848, 1684, 1589, 1506, 1468, 1433, $1385,1335,1277,1228,1122,864,768,721 \mathrm{~cm}^{-1} ;{ }^{1} \mathrm{H} \mathrm{NMR}\left(400 \mathrm{MHz}, \mathrm{CDCl}_{3}\right) \delta 0.88$ $(9 \mathrm{H}, \mathrm{t}, J=6.7 \mathrm{~Hz}) 1.21-1.40(48 \mathrm{H}, \mathrm{m}), 1.43-1.53(6 \mathrm{H}, \mathrm{m}), 172-1.86(6 \mathrm{H}, \mathrm{m}), 4.01-4.07$ $(6 \mathrm{H}, \mathrm{m}), 7.33(2 \mathrm{H}, \mathrm{s})$, a carboxyl proton was not clearly detected; ${ }^{13} \mathrm{C}$ NMR (100 MHz, $\left.\mathrm{CDCl}_{3}\right) \delta 14.10,22.69,26.04,26.07,29.25^{*}, 29.37^{*}, 29.56^{*}, 29.63^{*}, 29.66^{*}, 29.70^{*}$, $30.31,31.93,69.09,73.50,108.42,123.65,143.05,152.79,172.24$. Asterisks indicate overlapped peaks.

3,4,5-Tridodecyloxybenzoyl chloride 8c. A mixture of 7c (2.00 g, $2.40 \mathrm{mmol})$, anhydrous THF $(50 \mathrm{~mL})$, pyridine $(0.702 \mathrm{~g} 8.88 \mathrm{mmol})$, and thionyl chloride $(0.717 \mathrm{~mL}$, $5.92 \mathrm{mmol}$ ) was stirred at ambient temperature for $3 \mathrm{~h}$. After filtration, the solvent in the filtrate was removed under reduced pressure to give crude product including 8c (1.94 g) as a pale orange solid: ${ }^{1} \mathrm{H} \mathrm{NMR}\left(400 \mathrm{MHz}, \mathrm{CDCl}_{3}\right) \delta 0.88(9 \mathrm{H}, \mathrm{t}, J=6.7 \mathrm{~Hz}), 1.21-1.39$ $(48 \mathrm{H}, \mathrm{m}), 1.43-1.50(6 \mathrm{H}, \mathrm{m}), 1.73-1.86(6 \mathrm{H}, \mathrm{m}), 3.98-4.13(6 \mathrm{H}, \mathrm{m}), 7.33(2 \mathrm{H}, \mathrm{s}) ;{ }^{13} \mathrm{C}$ NMR (100 MHz, $\left.\mathrm{CDCl}_{3}\right) \delta 14.01,22.58,25.86,25.93,29.06^{*}, 29.25^{*}, 29.40^{*}, 29.50^{*}$, $29.55^{*}, 29.58^{*}, 30.00,30.17,30.20,31.81,69.16,73.58,109.75,127.19,144.53,152.71$, 167.56. Asterisks indicate overlapped peaks. Compound $8 \mathbf{c}$ was used for synthesis of $9 \mathbf{c}$ without further purification.

3,4,5-Tridodecyloxyphenyl isocyanate 9c. Sodium azide (1.21 g, $18.7 \mathrm{mmol})$ and benzyltriethylammonium chloride $(0.551 \mathrm{~g}, 2.42 \mathrm{mmol})$ were dissolved in water $(3 \mathrm{~mL})$ and the solution was cooled using an ice bath. To this solution, crude compound $8 \mathbf{c}(2.40$ 
$\mathrm{g})$ in the mixture of acetone $(9 \mathrm{~mL})$ and toluene $(6 \mathrm{~mL})$ was added dropwise at the temperature controlled between 10 and $15^{\circ} \mathrm{C}$. After addition completion, the mixture was stirred for $3 \mathrm{~h}$ and extracted with toluene. The combined organic layer was dried over anhydrous sodium sulfate. After filtration, the filtrate was heated at $90{ }^{\circ} \mathrm{C}$ for $1 \mathrm{~h}$, and the solvent of the solution was removed under reduced pressure to give crude product including 9c (2.18 g) as a pale orange solid: ${ }^{1} \mathrm{H} \mathrm{NMR}\left(400 \mathrm{MHz}, \mathrm{CDCl}_{3}\right) \delta 0.88(9 \mathrm{H}, \mathrm{t}$, $J=6.7 \mathrm{~Hz}), 1.16-1.39(48 \mathrm{H}, \mathrm{m}), 1.69-1.82(6 \mathrm{H}, \mathrm{m}), 3.84-3.94(6 \mathrm{H}, \mathrm{m}), 6.27(2 \mathrm{H}, \mathrm{s}) ;{ }^{13} \mathrm{C}$ NMR $\left(100 \mathrm{MHz}, \mathrm{CDCl}_{3}\right) \delta 14.06,22.66,26.00,26.06,29.19^{*}, 29.35^{*}, 29.61 *, 29.64 *$, $29.67^{*}, 29.71^{*}, 30.21^{*}, 31.90,69.03,73.47,103.23,124.33,128.38,136.02,153.40$. Asterisks indicate overlapped peaks. Compound $\mathbf{9 c}$ was used for synthesis of $\mathbf{C}_{\mathbf{1 2}} \mathbf{O}-\mathbf{0}$ without further purification.

Methyl 3,4,5-trihexadecyloxybenzoate 6d. A mixture of methyl gallate 5 (5.00 g, 27.2 $\mathrm{mmol})$, 1-bromohexadecane $(33.3 \mathrm{~g}, 109 \mathrm{mmol})$, and potassium carbonate $(16.2 \mathrm{~g}, 177$ mmol) in DMF (50 mL) was stirred at $100{ }^{\circ} \mathrm{C}$ for $20 \mathrm{~h}$. Chloroform was added to the mixture and this solution was washed with water. The organic layer was dried over anhydrous sodium sulfate. After filtration, the solvent in the filtrate was removed under reduced pressure. The residue was recrystallized from chloroform-methanol mixture to afford $\mathbf{6 d}$ (23.3 g $27.2 \mathrm{mmol}, 99 \%)$ as a colorless solid: IR (KBr) 2916, 2848, 1720, 1705, $1589,1469,1438,1385,1338,1225,764 \mathrm{~cm}^{-1} ;{ }^{1} \mathrm{H} \mathrm{NMR}\left(600 \mathrm{MHz}, \mathrm{CDCl}_{3}\right) \delta 0.88(9 \mathrm{H}$, $\mathrm{t}, J=7.2 \mathrm{~Hz}), 1.21-1.33(72 \mathrm{H}, \mathrm{m}), 1.44-1.51(6 \mathrm{H}, \mathrm{m}), 1.72-1.83(6 \mathrm{H}, \mathrm{m}), 3.88(3 \mathrm{H}, \mathrm{s})$, 3.99-4.03 (6H, m), $7.25(2 \mathrm{H}, \mathrm{s}) ;{ }^{13} \mathrm{C} \mathrm{NMR}\left(150 \mathrm{MHz}, \mathrm{CDCl}_{3}\right) \delta 14.07,22.65,26.04$, $29.26^{*}, 29.35^{*}, 29.54^{*}, 29.61^{*}, 29.64^{*}, 29.68^{*}, 30.29,31.89,52.01,69.07,73.41,107.88$, $124.59,142.27,152.76,166.86$. Asterisks indicate overlapped peaks.

3,4,5-Trihexadecyloxybenzoic acid $\mathbf{7 d}$. To a solution of $\mathbf{6 d}(5.00 \mathrm{~g}, 5.83 \mathrm{mmol})$ in ethanol $(100 \mathrm{~mL})$, potassium hydroxide $(0.718 \mathrm{~g}, 12.8 \mathrm{mmol})$ in water $(5 \mathrm{~mL})$ was added, and the mixture was refluxed for $19 \mathrm{~h}$. After solvent evaporation, $2 \mathrm{~mol} / \mathrm{L} \mathrm{HCl}$ aqueous solution $(50 \mathrm{~mL})$ was added and the mixture was extracted with diethyl ether. The combined organic layer was dried over anhydrous sodium sulfate. After filtration, the solvent in the filtrate was removed under reduced pressure to give $7 \mathbf{d}$ ( $3.23 \mathrm{~g}, 3.83 \mathrm{mmol}$, $66 \%$ ) as a colorless solid: IR (KBr) 2916, 2848, 1682, 1587, 1506, 1469, 1431, 1335, $1277,1227,1122,984,864,719 \mathrm{~cm}^{-1} ;{ }^{1} \mathrm{H}$ NMR $\left(600 \mathrm{MHz}, \mathrm{CDCl}_{3}\right) \delta 0.88(9 \mathrm{H}, \mathrm{t}, J=6.9$ $\mathrm{Hz}), 1.23-1.39$ (72H, m), 1.44-1.51 (6H, m), 1.72-1.84 (6H, m), 4.00-4.06 (6H, m), 7.32 $(2 \mathrm{H}, \mathrm{s})$, a carboxyl proton was not clearly detected; ${ }^{13} \mathrm{C} \mathrm{NMR}\left(150 \mathrm{MHz}, \mathrm{CDCl}_{3}\right) \delta 14.11$, $22.69,26.03,26.07,29.27 *, 29.38^{*}, 29.56^{*}, 29.63^{*}, 29.67^{*}, 29.71^{*}, 30.32,31.92,69.16$, $73.53,108.50,123.53,143.11,152.84,171.50$. Asterisks indicate overlapped peaks.

3,4,5-Trihexadecyloxybenzoyl chloride 8d. A mixture of 7d (1.01 g, $1.20 \mathrm{mmol}$ ), 
anhydrous THF $(15 \mathrm{~mL})$, and thionyl chloride $(0.259 \mathrm{~mL}, 3.60 \mathrm{mmol})$ was stirred at ambient temperature for $1 \mathrm{~h}$. THF and thionyl chloride remained in the mixture was removed by distillation under reduced pressure to give crude product including $\mathbf{8 d}(1.01$ g) as a pale orange solid: ${ }^{1} \mathrm{H} \mathrm{NMR}\left(600 \mathrm{MHz}, \mathrm{CDCl}_{3}\right) \delta 0.89(9 \mathrm{H}, \mathrm{t}, J=6.9 \mathrm{~Hz}), 1.16-$ $1.41(72 \mathrm{H}, \mathrm{m}), 1.42-1.54(6 \mathrm{H}, \mathrm{m}), 1.70-1.90$ (6H, m), 3.98-4.13 (6H, m), $7.33(2 \mathrm{H}, \mathrm{s})$; ${ }^{13} \mathrm{C}$ NMR (150 MHz, $\left.\mathrm{CDCl}_{3}\right) \delta 14.12,22.69,26.04,29.17^{*}, 29.27 *, 29.37 *, 29.50^{*}$, $29.71 *, 30.31,31.92,69.32,73.70,109.94,127.24,144.68,152.83,167.72$. Asterisks indicate overlapped peaks. Compound $\mathbf{8} \mathbf{d}$ was used for synthesis of $\mathbf{9} \mathbf{d}$ without further purification.

3,4,5-Trihexadecyloxyphenyl isocyanate $9 \mathbf{d}$. Sodium azide $(0.228 \mathrm{~g}, 3.51 \mathrm{mmol})$ and benzyltriethylammonium chloride $(0.401 \mathrm{~g}, 1.76 \mathrm{mmol})$ were dissolved in water $(2 \mathrm{~mL})$ and the solution was cooled using an ice bath. To this solution, crude compound $\mathbf{8 d}(1.01$ $\mathrm{g})$ in the mixture of acetone $(6 \mathrm{~mL})$ and toluene $(3 \mathrm{~mL})$ was added dropwise at the temperature controlled between 10 and $15^{\circ} \mathrm{C}$. After addition completion, the mixture was stirred for $3 \mathrm{~h}$ and extracted with toluene. The organic layer was combined and dried over anhydrous sodium sulfate. After filtration, the filtrate was heated at $90{ }^{\circ} \mathrm{C}$ for $1 \mathrm{~h}$, and the solvent of the solution was removed under reduced pressure to give crude product including 9d (1.19 g) as a pale orange solid: ${ }^{1} \mathrm{H}$ NMR $\left(600 \mathrm{MHz}, \mathrm{CDCl}_{3}\right) \delta 0.88(9 \mathrm{H}, \mathrm{t}$, $J=9.6 \mathrm{~Hz}), 1.15-1.39(72 \mathrm{H}, \mathrm{m}), 1.40-1.52(6 \mathrm{H}, \mathrm{m}), 1.65-1.87(6 \mathrm{H}, \mathrm{m}), 3.88-4.07(6 \mathrm{H}$, m), $6.27(2 \mathrm{H}, \mathrm{s}) ;{ }^{13} \mathrm{C} \mathrm{NMR}\left(150 \mathrm{MHz}, \mathrm{CDCl}_{3}\right) \delta 14.10,22.69,26.07,29.23 *, 29.36^{*}$, $29.71 *, 30.31,31.92,69.02,73.51,103.36,124.32,128.37,136.16,153.45$. Asterisks indicate overlapped peaks. Compound $\mathbf{9 d}$ was used for synthesis of $\mathbf{C}_{\mathbf{1 6}} \mathbf{O} \mathbf{- 0}$ without further purification.

\section{Reference}

(S2) Takahashi, R.; Nunokawa, T.; Shibuya, T.; Tomita, R.; Tatewaki, Y.; Okada, S.; Kimura, T.; Shimada, S.; Matsuda, H. Synthesis and Solid-State Polymerization of Butadiyne Derivatives with Trialkoxyphenylurethane Groups. Bull. Chem. Soc. Jpn. 2012, 85, 236-244. 
3. Synthesis of benzyl isocyanate

Benzyl isocyanates $\mathbf{1 5 a}-\mathbf{d}$ to synthesize the corresponding urethane derivatives of 5(Pyren-1-yl)penta-2,4-diyn-1-ol 4 were prepared from methyl 3,4,5-trialkyloxybenzoate $\mathbf{6 a}-\mathbf{d}$ according to Figure S4. Details of the synthesis procedures are described below.
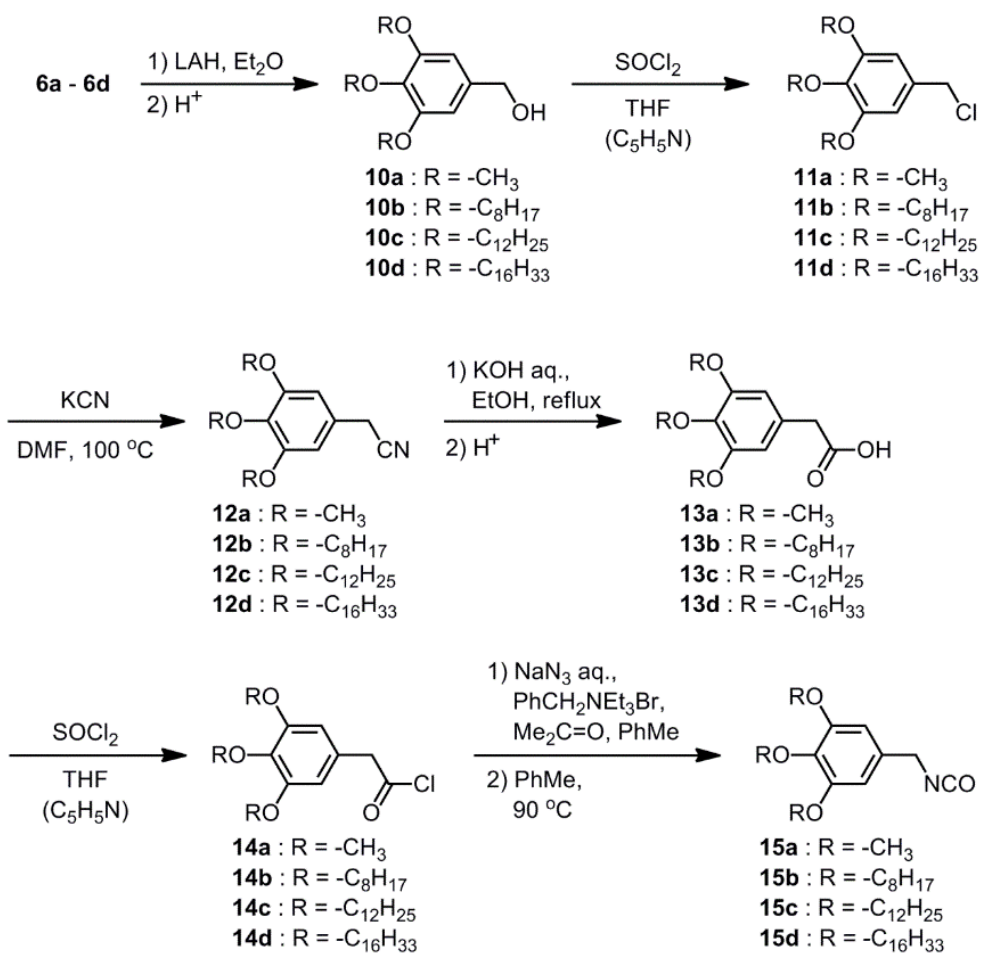

Figure S4 Synthesis scheme of $N$-benzyl isocyanate derivatives

(3,4,5-Trimethoxyphenyl)methanol 10a. To lithium aluminum hydride $(0.335 \mathrm{~g}, 8.84$ $\mathrm{mmol})$ dispersed in diethyl ether $(10 \mathrm{~mL}), 6 \mathrm{a}(1.00 \mathrm{~g}, 4.42 \mathrm{mmol})$ in diethyl ether $(10$ $\mathrm{mL}$ ) was added dropwise, and the mixture was stirred at ambient temperature for $1 \mathrm{~h}$. Then, methanol $(5 \mathrm{~mL})$ and $2 \mathrm{~mol} / \mathrm{L} \mathrm{HCl}$ aqueous solution $(5 \mathrm{~mL})$ were added, and the mixture was extracted with diethyl ether. The combined organic layer was dried over anhydrous sodium sulfate. After filtration, the solvent in the filtrate was removed under reduced pressure to give $10 \mathrm{a}(0.870 \mathrm{~g}, 4.38 \mathrm{mmol}, 99 \%)$ as a pale orange oil: IR (film) 3431, 2939, 2839, 1593, 1508, 1459, 1421, 1331, 1236, 1128, 1007, 960, 829, $779 \mathrm{~cm}^{-1}$; ${ }^{1} \mathrm{H}$ NMR (600 MHz, $\left.\mathrm{CDCl}_{3}\right) \delta 3.12(1 \mathrm{H}, \mathrm{brs}), 3.806(3 \mathrm{H}, \mathrm{s}), 3.811(6 \mathrm{H}, \mathrm{s}), 4.57(2 \mathrm{H}, \mathrm{s})$, $6.56(2 \mathrm{H}, \mathrm{s}) ;{ }^{13} \mathrm{C} \mathrm{NMR}\left(150 \mathrm{MHz}, \mathrm{CDCl}_{3}\right) \delta 55.73,60.56,64.81,103.39,136.65,136.77$, 152.91

5-Chloromethyl-1,2,3-trimethoxybenzene 11a. A mixture of 10a (0.870 g, 4.39 $\mathrm{mmol})$, THF $(10 \mathrm{~mL})$, pyridine $(0.694 \mathrm{~g}, 8.78 \mathrm{mmol})$, and thionyl chloride $(0.646 \mathrm{~mL}$, 
$8.78 \mathrm{mmol}$ ) was stirred at ambient temperature for $1 \mathrm{~h}$. After filtration, the solvent in the filtrate was removed under reduced pressure. The residue was purified by column chromatography (silica gel, chloroform) to give $11 \mathrm{a}(0.910 \mathrm{~g}, 4.20 \mathrm{mmol}, 96 \%)$ as a pale orange solid: IR (KBr) 2943, 2839, 1591, 1510, 1468, 1425, 1335, 1246, 1126, 995, 836, $700,631 \mathrm{~cm}^{-1}$; ${ }^{1} \mathrm{H} \mathrm{NMR}\left(600 \mathrm{MHz}, \mathrm{CDCl}_{3}\right) \delta 3.85(3 \mathrm{H}, \mathrm{s}), 3.87(6 \mathrm{H}, \mathrm{s}), 4.54(2 \mathrm{H}, \mathrm{s}), 6.61$ $(2 \mathrm{H}, \mathrm{s}) ;{ }^{13} \mathrm{C} \mathrm{NMR}\left(150 \mathrm{MHz}, \mathrm{CDCl}_{3}\right) \delta 46.75,56.07,60.78,105.60,132.89,138.00$, 153.27 .

2-(3,4,5-Trimethoxyphenyl)acetonitrile 12a. To a solution of 11a $(0.910 \mathrm{~g}, 4.20$ $\mathrm{mmol})$ in DMF $(20 \mathrm{~mL})$, sodium cyanide $(1.03 \mathrm{~g}, 21.0 \mathrm{mmol})$ in water $(5 \mathrm{~mL})$ was added, and the mixture was stirred at $100{ }^{\circ} \mathrm{C}$ for $6 \mathrm{~h}$. To this, water was added and the mixture was extracted with dichloromethane. The combined organic layer was washed with brine and dried over anhydrous sodium sulfate. After filtration, the solvent in the filtrate was removed under reduced pressure. The residue was purified by column chromatography (silica gel, chloroform) to give $12 \mathrm{a}(0.640 \mathrm{~g}, 3.09 \mathrm{mmol}, 74 \%)$ as a pale orange solid: IR (KBr) 2942, 2835, 2245, 1593, 1510, 1452, 1415, 1336, 1315, 1248, 1187, 1132, 997 , 823, 781, $690 \mathrm{~cm}^{-1}$; ${ }^{1} \mathrm{H}$ NMR (600 MHz, $\left.\mathrm{CDCl}_{3}\right) \delta 3.71(2 \mathrm{H}, \mathrm{s}), 3.81(3 \mathrm{H}, \mathrm{s}), 3.87(6 \mathrm{H}$, s), $6.53(2 \mathrm{H}, \mathrm{s}) ;{ }^{13} \mathrm{C} \mathrm{NMR}\left(150 \mathrm{MHz}, \mathrm{CDCl}_{3}\right) \delta 23.78,56.17,60.85,104.96,117.81$, $125.30,137.66,153.64$.

2-(3,4,5-Trimethoxyphenyl)acetic acid 13a. To a solution of $12 \mathbf{a}(1.53 \mathrm{~g}, 7.38 \mathrm{mmol})$ in ethanol $(50 \mathrm{~mL})$, potassium hydroxide $(8.30 \mathrm{~g}, 148 \mathrm{mmol})$ in water $(10 \mathrm{~mL})$ was added, and the mixture was refluxed for $21 \mathrm{~h}$. After the mixture was cooled to ambient temperature, it was acidified by slow addition of concentrated $\mathrm{HCl}$ aqueous solution to be approximately $\mathrm{pH} 1$ and then extracted with dichloromethane. The combined organic layer was washed with brine and dried over anhydrous sodium sulfate. After filtration, the solvent in the filtrate was evaporated to give 13a (1.64 g, $7.24 \mathrm{mmol}, 98 \%)$ as a colorless solid: IR (KBr) 2939, 2835, 1703, 1595, 1510, 1468, 1421, 1323, 1244, 1126, $1003,935,827,779,721,642 \mathrm{~cm}^{-1} ;{ }^{1} \mathrm{H}$ NMR $\left(600 \mathrm{MHz}, \mathrm{CDCl}_{3}\right) \delta 3.59(2 \mathrm{H}, \mathrm{s}), 3.83(3 \mathrm{H}$, s), $3.85(6 \mathrm{H}, \mathrm{s}), 6.51(2 \mathrm{H}, \mathrm{s})$, a carboxyl proton was not clearly detected; ${ }^{13} \mathrm{C}$ NMR (150 $\left.\mathrm{MHz}, \mathrm{CDCl}_{3}\right) \delta 41.29,56.04,60.77,106.38,128.75,137.17,153.21,177.53$.

2-(3,4,5-Trimethoxyphenyl)acetyl chloride 14a. To a solution of 13a $(0.452 \mathrm{~g}, 2.00$ mmol) in anhydrous THF $(30 \mathrm{~mL})$, thionyl chloride $(0.288 \mathrm{~mL}, 4.00 \mathrm{mmol})$ was added dropwise and the mixture was stirred at ambient temperature for $1 \mathrm{~h}$. The solvent and thionyl chloride remained in the mixture was removed by distillation under reduced pressure to give crude product including $14 \mathrm{a}(0.530 \mathrm{~g})$ as a pale orange solid: ${ }^{1} \mathrm{H} \mathrm{NMR}$ $(600 \mathrm{MHz}, \mathrm{CDCl}) \delta 3.84(3 \mathrm{H}, \mathrm{s}), 3.85(6 \mathrm{H}, \mathrm{s}), 4.08(2 \mathrm{H}, \mathrm{s}), 6.47(2 \mathrm{H}, \mathrm{s}) ;{ }^{13} \mathrm{C} \mathrm{NMR}(150$ $\left.\mathrm{MHz}, \mathrm{CDCl}_{3}\right) \delta 53.05,56.00,60.69,106.48,126.52,137.71,153.35,171.75$. Compound 
14a was used for synthesis of $15 \mathbf{a}$ without further purification.

(3,4,5-Trimethoxyphenyl)methyl isocyanate 15a. Sodium azide $(0.650 \mathrm{~g}, 10.0 \mathrm{mmol})$ and benzyltriethylammonium chloride $(0.683 \mathrm{~g}, 3.00 \mathrm{mmol})$ were dissolved in water (2 $\mathrm{mL}$ ) and the solution was cooled using an ice bath. To this solution, crude compound 14a $(0.530 \mathrm{~g})$ in the mixture of acetone $(6 \mathrm{~mL})$ and toluene $(3 \mathrm{~mL})$ was added dropwise at the temperature controlled between 10 and $15{ }^{\circ} \mathrm{C}$. After addition completion, the mixture was stirred for $2 \mathrm{~h}$ and extracted with toluene. The combined organic layer was dried over anhydrous sodium sulfate. After the filtration, the filtrate was heated at $90{ }^{\circ} \mathrm{C}$ for $1 \mathrm{~h}$, and the solvent was removed under reduced pressure to give crude product including 15a $(0.440 \mathrm{~g})$ as a pale orange solid: ${ }^{1} \mathrm{H} \mathrm{NMR}\left(600 \mathrm{MHz}, \mathrm{CDCl}_{3}\right) \delta 3.83(3 \mathrm{H}, \mathrm{s}), 3.85(6 \mathrm{H}, \mathrm{s})$, $4.42(2 \mathrm{H}, \mathrm{s}), 6.53(2 \mathrm{H}, \mathrm{s}) ;{ }^{13} \mathrm{C} \mathrm{NMR}\left(150 \mathrm{MHz}, \mathrm{CDCl}_{3}\right) \delta 46.38,55.78,60.48,103.46$, 123.11, 132.38, 137.18, 153.19. Compound 15a was used for synthesis of $\mathbf{C}_{\mathbf{1}} \mathbf{0} \mathbf{\mathbf { 1 }} \mathbf{1}$ without further purification.

(3,4,5-Trioctyloxyphenyl)methanol 10b. To lithium aluminum hydride (0.436 g, 11.5 $\mathrm{mmol})$ dispersed in diethyl ether $(20 \mathrm{~mL}), 6 \mathbf{b}(4.00 \mathrm{~g}, 7.68 \mathrm{mmol})$ in diethyl ether $(20$ $\mathrm{mL}$ ) was added dropwise, and the mixture was stirred at ambient temperature for $1 \mathrm{~h}$. Then, methanol $(10 \mathrm{~mL})$ and $2 \mathrm{~mol} / \mathrm{L} \mathrm{HCl}$ aqueous solution $(10 \mathrm{~mL})$ were added, and the mixture was extracted with diethyl ether. The combined organic layer was dried over anhydrous sodium sulfate. After filtration, the solvent in the filtrate was removed under reduced pressure to give 10b (3.68 g, $7.47 \mathrm{mmol}, 97 \%)$ as a colorless solid: IR (KBr) 3307, 2929, 2858, 1591, 1504, 1467, 1441, 1392, 1335, 1230, 1126, 1076, 987, 831, 723 $\mathrm{cm}^{-1} ;{ }^{1} \mathrm{H}$ NMR $\left(600 \mathrm{MHz}, \mathrm{CDCl}_{3}\right) \delta 0.89(9 \mathrm{H}, \mathrm{t}, J=6.9 \mathrm{~Hz}), 1.23-1.38(24 \mathrm{H}, \mathrm{m}), 1.42-$ $1.50(6 \mathrm{H}, \mathrm{m}), 1.71-1.82(6 \mathrm{H}, \mathrm{m}), 2.21(1 \mathrm{H}, \mathrm{brs}), 3.91-3.95(6 \mathrm{H}, \mathrm{m}), 4.55(2 \mathrm{H}, \mathrm{s}), 6.52$ $(2 \mathrm{H}, \mathrm{s}) ;{ }^{13} \mathrm{C} \mathrm{NMR}\left(150 \mathrm{MHz}, \mathrm{CDCl}_{3}\right) \delta 14.02,22.61,22.63,26.04,29.24 *, 29.32 *, 29.34^{*}$, $29.49^{*}, 30.23,31.77^{*}, 31.85^{*}, 65.40,68.94,73.36,105.08,136.14,137.23,153.07$. Asterisks indicate overlapped peaks.

5-Chloromethyl-1,2,3-trioctyloxybenzene 11b. A mixture of 10b (1.23 g, $2.50 \mathrm{mmol})$, THF (20 mL), pyridine (0.593 g, $7.50 \mathrm{mmol})$, and thionyl chloride $(0.363 \mathrm{~mL}, 5.00 \mathrm{mmol})$ was stirred at ambient temperature for $1 \mathrm{~h}$. After filtration, the solvent in the filtrate was removed under reduced pressure. The residue was purified by column chromatography (silica gel, chloroform) to give $11 \mathrm{~b}(1.23 \mathrm{~g}, 2.41 \mathrm{mmol}, 96 \%)$ as a pale orange liquid: IR (film) 2929, 2854, 1591, 1504, 1468, 1440, 1379, 1336, 1236, 1115, 956, 831, $758 \mathrm{~cm}^{-1}$; ${ }^{1} \mathrm{H}$ NMR $\left(600 \mathrm{MHz}, \mathrm{CDCl}_{3}\right) \delta 0.86-0.91(9 \mathrm{H}, \mathrm{m}), 1.12-1.39(24 \mathrm{H}, \mathrm{m}), 1.43-1.52(6 \mathrm{H}$, $\mathrm{m}), 1.70-1.83(6 \mathrm{H}, \mathrm{m}), 3.91-3.97(6 \mathrm{H}, \mathrm{m}), 4.46(2 \mathrm{H}, \mathrm{s}), 6.55(2 \mathrm{H}, \mathrm{s}) ;{ }^{13} \mathrm{C} \mathrm{NMR}(150$ $\left.\mathrm{MHz}, \mathrm{CDCl}_{3}\right) \delta 13.91,22.54,25.99,29.18^{*}, 29.26^{*}, 29.42^{*}, 30.23^{*}, 31.71^{*}, 31.79^{*}$, $46.65,68.86,73.17,106.80,132.22,138.07,153.01$. Asterisks indicate overlapped peaks. 
2-(3,4,5-Trioctyloxyphenyl)acetonitrile $\mathbf{1 2 b}$. To a solution of $\mathbf{1 1 b}(1.28 \mathrm{~g}, 2.50 \mathrm{mmol})$ in DMF $(20 \mathrm{~mL})$, sodium cyanide $(1.23 \mathrm{~g}, 25.0 \mathrm{mmol})$ in water $(5 \mathrm{~mL})$ was added, and the mixture was stirred at $100{ }^{\circ} \mathrm{C}$ for $39 \mathrm{~h}$. To this, water was added and the mixture was extracted with dichloromethane. The combined organic layer was washed with brine and dried over anhydrous sodium sulfate. After filtration, the solvent in the filtrate was removed under reduced pressure. The residue was purified by column chromatography (silica gel, chloroform) and recrystallized from chloroform-methanol mixture to afford 12b (0.900 g, $1.79 \mathrm{mmol}, 72 \%)$ as a pale orange oil: IR (film) 2954, 2856, 2251, 1593 , 1506, 1468, 1441, 1381, 1336, 1242, 1115, 812, $723 \mathrm{~cm}^{-1} ;{ }^{1} \mathrm{H}$ NMR (600 MHz, $\left.\mathrm{CDCl}_{3}\right)$ $\delta 0.86-0.891(9 \mathrm{H}, \mathrm{m}), 1.23-1.38(24 \mathrm{H}, \mathrm{m}), 1.43-1.50(6 \mathrm{H}, \mathrm{m}), 1.71-1.82(6 \mathrm{H}, \mathrm{m}), 3.66$ $(2 \mathrm{H}, \mathrm{s}), 3.92-3.97(6 \mathrm{H}, \mathrm{m}), 6.48(2 \mathrm{H}, \mathrm{s}) ;{ }^{13} \mathrm{C} \mathrm{NMR}\left(150 \mathrm{MHz}, \mathrm{CDCl}_{3}\right) \delta 14.08,22.65$, $23.75,26.04,26.08,29.27^{*}, 29.33^{*}, 29.36^{*}, 29.52,30.28,31.81,31.88,69.20,73.46$, $106.30,118.01,124.65,137.78,153.55$. Asterisks indicate overlapped peaks.

2-(3,4,5-Trioctyloxyphenyl)acetic acid 13b. To a solution of $\mathbf{1 2 b}(0.520 \mathrm{~g}, 1.00$ $\mathrm{mmol})$ in ethanol $(30 \mathrm{~mL})$, potassium hydroxide $(0.560 \mathrm{~g}, 10.0 \mathrm{mmol})$ in water $(5 \mathrm{~mL})$ was added, and the mixture was refluxed for $19 \mathrm{~h}$. After the mixture was cooled to ambient temperature, it was acidified by slow addition of concentrated $\mathrm{HCl}$ aqueous solution to be approximately $\mathrm{pH} 1$ and then extracted with dichloromethane. The combined organic layer was washed with brine and dried over anhydrous sodium sulfate. After filtration, the solvent in the filtrate was removed under reduced pressure. The residue was purified by column chromatography (silica gel, chloroform) to give $13 \mathbf{b}(0.340 \mathrm{~g}, 0.653 \mathrm{mmol}$, $65 \%$ ) as a pale orange solid: IR ( $\mathrm{KBr}) 2929,2852,1714,1695,1593,1508,1468,1441$, 1390, 1338, 1319, 1296, 1244, 1117, 1065, $953 \mathrm{~cm}^{-1} ;{ }^{1} \mathrm{H}$ NMR (600 MHz, $\left.\mathrm{CDCl}_{3}\right) \delta 0.88$ $(9 \mathrm{H}, \mathrm{t}, J=6.5 \mathrm{~Hz}), 1.28-1.36(24 \mathrm{H}, \mathrm{m}), 1.43-1.48(6 \mathrm{H}, \mathrm{m}), 1.71-1.81(6 \mathrm{H}, \mathrm{m}), 3.54(2 \mathrm{H}$, s), 3.91-3.96 (6H, m), $6.46(2 \mathrm{H}, \mathrm{s})$, a carboxyl proton was not clearly detected; ${ }^{13} \mathrm{C} \mathrm{NMR}$ $\left(150 \mathrm{MHz}, \mathrm{CDCl}_{3}\right) \delta 14.09,22.66,22.68,26.07,29.28^{*}, 29.36^{*}, 29.54 *, 30.30,31.82^{*}$, $31.89^{*}, 41.26,69.06,73.41,107.77,128.18,137.38,153.14,177.23$. Asterisks indicate overlapped peaks.

2-(3,4,5-Trioctyloxyphenyl)acetyl chloride $\mathbf{1 4 b}$. To a solution of $\mathbf{1 3 b}(0.300 \mathrm{~g}, 0.576$ $\mathrm{mmol})$ in anhydrous THF $(20 \mathrm{~mL})$, thionyl chloride $(0.124 \mathrm{~mL}, 1.73 \mathrm{mmol})$ was added dropwise and the mixture was stirred at ambient temperature for $1 \mathrm{~h}$. The solvent and thionyl chloride remained in the mixture was removed by distillation under reduced pressure to give crude product including $14 \mathbf{b}(0.350 \mathrm{~g})$ as a pale orange solid: ${ }^{1} \mathrm{H}$ NMR $\left(600 \mathrm{MHz}, \mathrm{CDCl}_{3}\right) \delta 0.89(9 \mathrm{H}, \mathrm{t}, J=6.9 \mathrm{~Hz}), 1.23-1.39(24 \mathrm{H}, \mathrm{m}), 1.43-1.51(6 \mathrm{H}, \mathrm{m})$, 1.71-1.82 (6H, m), 3.91-4.13 (6H, m), $4.01(2 \mathrm{H}, \mathrm{s}), 6.43(2 \mathrm{H}, \mathrm{s}) ;{ }^{13} \mathrm{C}$ NMR (150 MHz, $\left.\mathrm{CDCl}_{3}\right) \delta 13.93,22.53,22.56,25.95^{*}, 25.97 *, 29.16^{*}, 29.22 *, 29.40,30.19,31.69,31.77$, 
53.03, 68.95, 73.25, 107.78, 125.90, 137.84, 153.20, 171.68. Asterisks indicate overlapped peaks. Compound 14b was used for synthesis of $\mathbf{1 5 b}$ without further purification.

(3,4,5-Trioctyloxyphenyl)methyl isocyanate $15 \mathrm{~b}$. Sodium azide $(0.112 \mathrm{~g}, 1.73 \mathrm{mmol})$ and benzyltriethylammonium chloride $(0.197 \mathrm{~g}, 0.864 \mathrm{mmol})$ were dissolved in water (2 $\mathrm{mL}$ ), and the solution was cooled using an ice bath. To this solution, crude compound $14 \mathbf{b}(0.330 \mathrm{~g})$ in the mixture of acetone $(6 \mathrm{~mL})$ and toluene $(3 \mathrm{~mL})$ was added dropwise at the temperature controlled between 10 and $15{ }^{\circ} \mathrm{C}$. After addition completion, the mixture was stirred for $2 \mathrm{~h}$, and it was extracted with toluene. The combined organic layer was dried over anhydrous sodium sulfate. After the filtration, the filtrate was heated at 90 ${ }^{\circ} \mathrm{C}$ for $1 \mathrm{~h}$, and the solvent was removed under reduced pressure to give crude product including $15 \mathbf{b}(0.270 \mathrm{~g})$ as a pale orange solid: ${ }^{1} \mathrm{H} \mathrm{NMR}\left(600 \mathrm{MHz}, \mathrm{CDCl}_{3}\right) \delta 0.89(9 \mathrm{H}$, $\mathrm{t}, J=6.9 \mathrm{~Hz}), 1.20-1.40(24 \mathrm{H}, \mathrm{m}), 1.40-1.48(6 \mathrm{H}, \mathrm{m}), 1.70-1.82(6 \mathrm{H}, \mathrm{m}), 3.88-3.98(6 \mathrm{H}$, $\mathrm{m}), 4.36(2 \mathrm{H}, \mathrm{s}), 6.47(2 \mathrm{H}, \mathrm{s}) ;{ }^{13} \mathrm{C} \mathrm{NMR}\left(150 \mathrm{MHz}, \mathrm{CDCl}_{3}\right) \delta 13.94,22.54,25.97,29.17^{*}$, 29.26*, 29.42, 30.20, 31.70, 31.79, 46.56, 68.94, 73.26, 104.91, 123.28, 131.90, 137.53, 153.23. Asterisks indicate overlapped peaks. Compound 15b was used for synthesis of $\mathrm{C}_{8} \mathrm{O}-1$ without further purification.

3,4,5-(Tridodecyloxyphenyl)methanol 10c. To lithium aluminum hydride $(0.550 \mathrm{~g}$, $14.5 \mathrm{mmol})$ dispersed in diethyl ether $(40 \mathrm{~mL}), 6 \mathrm{c}(5.80 \mathrm{~g}, 8.42 \mathrm{mmol})$ in diethyl ether $(40 \mathrm{~mL})$ was added dropwise, and the mixture was stirred at ambient temperature for $1 \mathrm{~h}$. Then, methanol $(10 \mathrm{~mL})$ and $2 \mathrm{~mol} / \mathrm{L} \mathrm{HCl}$ aqueous solution $(10 \mathrm{~mL})$ were added, and the mixture was extracted with diethyl ether. The combined organic layer was dried over anhydrous sodium sulfate. After filtration, the solvent in the filtrate was removed under reduced pressure to give $10 \mathrm{c}(5.72 \mathrm{~g}, 8.03 \mathrm{mmol}, 95 \%)$ as a white solid: IR (KBr) 3305, 2918, 2850, 1591, 1506, 1469, 1439, 1385, 1336, 1227, 1124, 1063, 1016, 995, 829, 808, $721 \mathrm{~cm}^{-1} ;{ }^{1} \mathrm{H}$ NMR $\left(600 \mathrm{MHz}, \mathrm{CDCl}_{3}\right) \delta 0.88(9 \mathrm{H}, \mathrm{t}, J=6.9 \mathrm{~Hz}), 1.22-1.38(48 \mathrm{H}, \mathrm{m})$, $1.43-1.50(6 \mathrm{H}, \mathrm{m}), 1.70-1.83(7 \mathrm{H}, \mathrm{m}), 3.92-3.97(6 \mathrm{H}, \mathrm{m}), 4.58(2 \mathrm{H}, \mathrm{s}), 6.54(2 \mathrm{H}, \mathrm{s}) ;{ }^{13} \mathrm{C}$ NMR (100 MHz, $\left.\mathrm{CDCl}_{3}\right) \delta 14.09,22.68,26.09,26.12,29.36^{*}, 29.40^{*}, 29.64 *, 29.69^{*}$, $29.75^{*}, 30.30,31.91,65.061,69.06,73.41,105.27,136.05,137.50,153.23$. Asterisks indicate overlapped peaks.

5-Chloromethyl-1,2,3-tridodecyloxybenzene 11c. A mixture of 10c (5.31 g, 8.03 mmol), THF ( $80 \mathrm{~mL})$, pyridine $(1.91 \mathrm{~g}, 24.1 \mathrm{mmol})$, and thionyl chloride $(1.17 \mathrm{~mL}, 16.1$ mmol) was stirred at ambient temperature for $1 \mathrm{~h}$. After filtration, the solvent in the filtrate was removed under reduced pressure. The residue was purified by column chromatography (silica gel, chloroform) to give $11 \mathrm{c}(5.21 \mathrm{~g}, 7.67 \mathrm{mmol}, 96 \%)$ as a pale orange solid: IR (KBr) 3421, 2920, 2848, 1593, 1506, 1466, 1441, 1392, 1335, 1246, 
$1163,1124,1163,1124,1066,987,951,829,723,700,673,613,580 \mathrm{~cm}^{-1} ;{ }^{1} \mathrm{H}$ NMR $(600$ $\left.\mathrm{MHz}, \mathrm{CDCl}_{3}\right) \delta 0.88(9 \mathrm{H}, \mathrm{t}, J=6.9 \mathrm{~Hz}), 1.21-1.38(48 \mathrm{H}, \mathrm{m}), 1.43-1.50(6 \mathrm{H}, \mathrm{m}), 1.72-$ $1.82(6 \mathrm{H}, \mathrm{m}), 3.92-3.99(6 \mathrm{H}, \mathrm{m}), 4.50(2 \mathrm{H}, \mathrm{s}), 6.57(2 \mathrm{H}, \mathrm{s}) ;{ }^{13} \mathrm{C} \mathrm{NMR}\left(150 \mathrm{MHz}, \mathrm{CDCl}_{3}\right)$ $\delta 14.08,22.67,26.07,26.10,29.36^{*}, 29.39^{*}, 29.62^{*}, 29.64^{*}, 29.68^{*}, 29.74 *, 30.30$, $31.92,46.94,69.09,73.40,107.02,132.29,138.26,153.18$. Asterisks indicate overlapped peaks.

2-(3,4,5-Tridodecyloxyphenyl)acetonitrile 12c. To a solution of 11c (5.21 g, 7.67 $\mathrm{mmol})$ in DMF $(100 \mathrm{~mL})$, sodium cyanide $(1.88 \mathrm{~g}, 38.4 \mathrm{mmol})$ in water $(5 \mathrm{~mL})$ was added, and the mixture was stirred at $100{ }^{\circ} \mathrm{C}$ for $12 \mathrm{~h}$. To this, water was added and the mixture was extracted with dichloromethane. The combined organic layer was washed with brine and dried over anhydrous sodium sulfate. After filtration, the solvent in the filtrate was removed under reduced pressure. The residue was purified by column chromatography (silica gel, chloroform) and recrystallized from chloroform-methanol mixture to afford 12c (4.35 g, $6.49 \mathrm{mmol}, 85 \%)$ as a pale orange solid: IR (KBr) 2920, 2848, 2249, 1595 , 1506, 1466, 1442, 1392, 1336, 1250, 1124, 816, $723 \mathrm{~cm}^{-1} ;{ }^{1} \mathrm{H}$ NMR (600 MHz, $\left.\mathrm{CDCl}_{3}\right)$ $\delta 0.88(9 \mathrm{H}, \mathrm{t}, J=6.9 \mathrm{~Hz}), 1.22-1.38(48 \mathrm{H}, \mathrm{m}), 1.43-1.50(6 \mathrm{H}, \mathrm{m}), 1.71-1.82(6 \mathrm{H}, \mathrm{m})$, $3.65(2 \mathrm{H}, \mathrm{s}), 3.92-3.97(6 \mathrm{H}, \mathrm{m}), 6.48(2 \mathrm{H}, \mathrm{s}) ;{ }^{13} \mathrm{C} \mathrm{NMR}\left(150 \mathrm{MHz}, \mathrm{CDCl}_{3}\right) \delta 14.08,22.66$, $23.72,26.04,26.09,29.35^{*}, 29.38^{*}, 29.58^{*}, 29.61^{*}, 29.63^{*}, 29.67^{*}, 29.72^{*}, 30.28,31.90$, $69.20,73.44,106.31,117.97,124.65,137.80,153.55$. Asterisks indicate overlapped peaks.

2-(3,4,5-Tridodecyloxyphenyl)acetic acid 13c. To a solution of 12c (4.35 g, 6.49 $\mathrm{mmol})$ in ethanol $(80 \mathrm{~mL})$, potassium hydroxide $(7.29 \mathrm{~g}, 130 \mathrm{mmol})$ in water $(10 \mathrm{~mL})$ was added, and the mixture was refluxed for $40 \mathrm{~h}$. After the mixture was cooled to ambient temperature, it was acidified by slow addition of concentrated $\mathrm{HCl}$ aqueous solution to be approximately $\mathrm{pH} 1$ and then extracted with dichloromethane. The combined organic layer was washed with brine and dried over anhydrous sodium sulfate. After filtration, the solvent in the filtrate was removed under reduced pressure. The residue was purified by column chromatography ( silica gel, chloroform) to give 13c (4.13 g, $5.99 \mathrm{mmol}, 92 \%)$ as a pale orange solid: IR (KBr) 2920, 2850, 1708, 1591, 1506, 1468, 1441, 1390, 1335, 1246, 1120, 966, $719 \mathrm{~cm}^{-1}$; ${ }^{1} \mathrm{H}$ NMR (600 MHz, $\left.\mathrm{CDCl}_{3}\right) \delta 0.88(9 \mathrm{H}, \mathrm{t}, J=7.2 \mathrm{~Hz}), 1.22-$ $1.37(48 \mathrm{H}, \mathrm{m}), 1.42-1.49(6 \mathrm{H}, \mathrm{m}), 1.70-1.81(6 \mathrm{H}, \mathrm{m}), 3.52(2 \mathrm{H}, \mathrm{s}), 3.90-3.96(6 \mathrm{H}, \mathrm{m})$, $6.46(2 \mathrm{H}, \mathrm{s})$, a carboxyl proton was not clearly detected; ${ }^{13} \mathrm{C} \mathrm{NMR}\left(150 \mathrm{MHz}, \mathrm{CDCl}_{3}\right) \delta$ $14.08,22.67,26.09,26.12,29.36^{*}, 29.39 *, 29.40 *, 29.42 *, 29.64 *, 29.69 *, 29.74 * 30.31$, $31.91,41.34,69.08,73.40,107.82,128.16,137.43,153.14,177.75$. Asterisks indicate overlapped peaks.

2-(3,4,5-Tridodecyloxyphenyl)acetyl chloride 14c. To a solution of $13 \mathrm{c}(1.38 \mathrm{~g}, 2.00$ $\mathrm{mmol})$ in anhydrous THF $(40 \mathrm{~mL})$, thionyl chloride $(1.44 \mathrm{~mL}, 20.0 \mathrm{mmol})$ was added 
dropwise and the mixture was stirred at ambient temperature for $1 \mathrm{~h}$. The solvent and thionyl chloride remained in the mixture was removed by distillation under reduced pressure to give crude product including 14c $(1.40 \mathrm{~g})$ as a pale orange solid: ${ }^{1} \mathrm{H} \mathrm{NMR}$ $\left(600 \mathrm{MHz}, \mathrm{CDCl}_{3}\right) \delta 0.88(9 \mathrm{H}, \mathrm{t}, J=6.9 \mathrm{~Hz}), 1.22-1.37(48 \mathrm{H}, \mathrm{m}), 1.43-1.50(6 \mathrm{H}, \mathrm{m})$, 1.70-1.82 (6H, m), 3.92-3.97 (6H, m), $4.02(2 \mathrm{H}, \mathrm{s}), 6.43(2 \mathrm{H}, \mathrm{s}) ;{ }^{13} \mathrm{C}$ NMR (150 MHz, $\left.\mathrm{CDCl}_{3}\right) \delta 14.08,22.66,26.05,29.34^{*}, 29.39^{*}, 29.58^{*}, 29.61^{*}, 29.63^{*}, 29.67 *, 29.73^{*}$, 30.30, 31.90, 53.20, 69.14, 73.39, 107.97, 125.93, 138.08, 153.35, 171.84. Asterisks indicate overlapped peaks. Compound 14c was used for synthesis of $15 \mathrm{c}$ without further purification.

(3,4,5-Tridodecyloxyphenyl)methyl isocyanate 15c. Sodium azide $(0.650 \mathrm{~g}, 10.0$ $\mathrm{mmol})$ and benzyltriethylammonium chloride $(0.680 \mathrm{~g}, 3.00 \mathrm{mmol})$ were dissolved in water $(2 \mathrm{~mL})$, and the solution was cooled using an ice bath. To this solution, crude compound 14c $(1.40 \mathrm{~g})$ in the mixture of acetone $(6 \mathrm{~mL})$ and toluene $(3 \mathrm{~mL})$ was added dropwise at the temperature controlled between 10 and $15^{\circ} \mathrm{C}$. After addition completion, the mixture was stirred for $2 \mathrm{~h}$, and it was extracted with toluene. The combined organic layer was dried over anhydrous sodium sulfate. After the filtration, the filtrate was heated at $90{ }^{\circ} \mathrm{C}$ for $1 \mathrm{~h}$, and the solvent was removed under reduced pressure to give crude product including 15c $(1.36 \mathrm{~g})$ as a pale orange solid: ${ }^{1} \mathrm{H} \mathrm{NMR}\left(600 \mathrm{MHz}, \mathrm{CDCl}_{3}\right) \delta 0.89$ $(9 \mathrm{H}, \mathrm{t}, J=6.9 \mathrm{~Hz}), 1.27-1.31(48 \mathrm{H}, \mathrm{m}), 1.43-1.52(6 \mathrm{H}, \mathrm{m}), 1.72-1.78(6 \mathrm{H}, \mathrm{m}), 3.85-$ $3.96(6 \mathrm{H}, \mathrm{m}), 4.21(2 \mathrm{H}, \mathrm{s}), 6.41(2 \mathrm{H}, \mathrm{s}) ;{ }^{13} \mathrm{C} \mathrm{NMR}\left(150 \mathrm{MHz}, \mathrm{CDCl}_{3}\right) \delta 13.90,21.12$, $22.58,26.00,29.57 *, 29.59 *, 29.62 *, 29.68 *, 30.27,31.84,46.41,68.83,73.10,104.86$, 123.46, 131.89, 137.40, 153.24. Asterisks indicate overlapped peaks. Compound 15c was used for synthesis of $\mathbf{C}_{\mathbf{1 2}} \mathbf{O} \mathbf{- 1}$ without further purification.

(3,4,5-Trihexadecyloxyphenyl)methanol 10d. To lithium aluminum hydride $(0.332 \mathrm{~g}$, $8.75 \mathrm{mmol})$ dispersed in diethyl ether $(50 \mathrm{~mL}), 6 \mathrm{~d}(5.00 \mathrm{~g}, 5.58 \mathrm{mmol})$ in diethyl ether $(50 \mathrm{~mL})$ was added dropwise, and the mixture was stirred at ambient temperature for $1 \mathrm{~h}$. Then, methanol $(10 \mathrm{~mL})$ and $2 \mathrm{~mol} / \mathrm{L} \mathrm{HCl}$ aqueous solution $(10 \mathrm{~mL})$ were added, and the mixture was extracted with diethyl ether. The combined organic layer was dried over anhydrous sodium sulfate. After filtration, the solvent in the filtrate was removed under reduced pressure to give $10 \mathrm{~d}$ (4.33 g, $5.22 \mathrm{mmol}, 90 \%)$ as a white solid: IR (KBr) 3307, 2924, 2848, 1591, 1506, 1471, 1439, 1382, 1336, 1226, 1124, 806, $721 \mathrm{~cm}^{-1}$; ${ }^{1} \mathrm{H}$ NMR $\left(600 \mathrm{MHz} \mathrm{CDCl}_{3}\right) \delta 0.88(9 \mathrm{H}, \mathrm{t}, J=7.2 \mathrm{~Hz}), 1.22-1.36(72 \mathrm{H}, \mathrm{m}), 1.43-1.49(6 \mathrm{H}, \mathrm{m})$, $1.68-1.82(7 \mathrm{H}, \mathrm{m}), 3.92-3.97(6 \mathrm{H}, \mathrm{m}), 4.59(2 \mathrm{H}, \mathrm{s}), 6.55(2 \mathrm{H}, \mathrm{s}) ;{ }^{13} \mathrm{C}$ NMR (150 MHz, $\left.\mathrm{CDCl}_{3}\right) \delta 14.10,22.68,26.09,26.12,29.37^{*}, 29.40^{*}, 29.61^{*}, 29.65^{*}, 29.71 *, 30.30$, $31.92,65.62,69.06,73.41,105.27,136.05,137.47,153.23$. Asterisks indicate overlapped peaks. 
5-Chloromethyl-1,2,3-trihexadecyloxybenzene 11d. A mixture of 10d (4.15 g, 5.00 $\mathrm{mmol})$, THF ( $80 \mathrm{~mL})$, pyridine $(1.19 \mathrm{~g}, 15.0 \mathrm{mmol})$, and thionyl chloride $(0.726 \mathrm{~mL}, 10.0$ mmol) was stirred at ambient temperature for $1 \mathrm{~h}$. After filtration, the solvent in the filtrate was removed under reduced pressure. The residue was purified by column chromatography (silica gel, chloroform) to give 11d (3.95 g, $4.66 \mathrm{mmol}, 93 \%$ ) as a pale orange solid: IR (KBr) 2914, 2848, 1592, 1506, 1468, 1442, 1392, 1333, 1246, 1124, $1065,949,827,721 \mathrm{~cm}^{-1},{ }^{1} \mathrm{H}$ NMR $\left(600 \mathrm{MHz}, \mathrm{CDCl}_{3}\right) \delta 0.88(9 \mathrm{H}, \mathrm{t}, J=7.2 \mathrm{~Hz}), 1.19$ $1.39(72 \mathrm{H}, \mathrm{m}), 1.42-1.50(6 \mathrm{H}, \mathrm{m}), 1.72-1.82(6 \mathrm{H}, \mathrm{m}), 3.93-3.97(6 \mathrm{H}, \mathrm{m}), 4.50(2 \mathrm{H}, \mathrm{s})$, $6.56(2 \mathrm{H}, \mathrm{s}) ;{ }^{13} \mathrm{C} \mathrm{NMR}\left(150 \mathrm{MHz}, \mathrm{CDCl}_{3}\right) \delta 14.09,22.68,26.07,29.10,29.37^{*}, 29.39^{*}$, $29.60 *, 29.63 *, 29.66 *, 29.71 *, 30.30,31.92,46.94,69.08,73.41,106.99,132.29,138.23$, 153.18. Asterisks indicate overlapped peaks.

2-(3,4,5-Trihexadecyloxyphenyl)acetonitrile $\mathbf{1 2 d}$. To a solution of $\mathbf{1 1 d}$ (3.95 g, 4.66 $\mathrm{mmol})$ in DMF $(50 \mathrm{~mL})$, sodium cyanide $(2.28 \mathrm{~g}, 46.6 \mathrm{mmol})$ in water $(5 \mathrm{~mL})$ was added, and the mixture was stirred at $100{ }^{\circ} \mathrm{C}$ for $25 \mathrm{~h}$. To this, water was added and the mixture was extracted with dichloromethane. The combined organic layer was washed with brine and dried over anhydrous sodium sulfate. After filtration, the solvent in the filtrate was removed under reduced pressure. The residue was purified by column chromatography (silica gel, chloroform) and recrystallized from a mixture of chloroform and methanol to afford 12d (2.54 g, $3.03 \mathrm{mmol}, 65 \%)$ as a pale orange solid: IR (KBr) 2918, 2848, 2249, 1595, 1506, 1468, 1442, 1392, 1336, 1250, 1124, 1065, $721 \mathrm{~cm}^{-1}$; ${ }^{1} \mathrm{H}$ NMR (600 MHz, $\left.\mathrm{CDCl}_{3}\right) \delta 0.88(9 \mathrm{H}, \mathrm{t}, J=7.2 \mathrm{~Hz}), 1.23-1.37(72 \mathrm{H}, \mathrm{m}), 1.43-1.50(6 \mathrm{H}, \mathrm{m}), 1.72-1.81(6 \mathrm{H}$, m), $3.66(2 \mathrm{H}, \mathrm{s}), 3.92-3.99(6 \mathrm{H}, \mathrm{m}), 6.48(2 \mathrm{H}, \mathrm{s}) ;{ }^{13} \mathrm{C} \mathrm{NMR}\left(150 \mathrm{MHz}, \mathrm{CDCl}_{3}\right) \delta 14.09$, $22.68,23.74,26.05,26.10,29.34^{*}, 29.36^{*}, 29.39^{*}, 29.59^{*}, 29.62^{*}, 29.66^{*}, 29.70^{*}$, $29.73^{*}, 30.29,31.92,69.21,73.45,106.33,117.98,124.65,137.82,153.56$. Asterisks indicate overlapped peaks.

2-(3,4,5-Trihexadecyloxyphenyl)acetic acid 13d. To a solution of $\mathbf{1 2 d}(2.54 \mathrm{~g}, 3.03$ $\mathrm{mmol})$ in ethanol $(80 \mathrm{~mL})$, potassium hydroxide $(1.70 \mathrm{~g}, 30.3 \mathrm{mmol})$ in water $(10 \mathrm{~mL})$ was added, and the mixture was refluxed for $21 \mathrm{~h}$. After the mixture was cooled to ambient temperature, it was acidified by slow addition of concentrated $\mathrm{HCl}$ aqueous solution to be approximately $\mathrm{pH} 1$ and then extracted with dichloromethane. The combined organic layer was washed with brine and dried over anhydrous sodium sulfate. After filtration, the solvent in the filtrate was removed under reduced pressure. The residue was purified by column chromatography (silica gel, chloroform) to give 13d (2.05 g, $2.39 \mathrm{mmol}, 79 \%)$ as a pale orange solid: IR (KBr) 2922, 2852, 1695, 1591, 1508, 1468, 1441, 1390, 1338, $1244,1117,1065,1009,953,723 \mathrm{~cm}^{-1} ;{ }^{1} \mathrm{H} \mathrm{NMR}\left(600 \mathrm{MHz}, \mathrm{CDCl}_{3}\right) \delta 0.88(9 \mathrm{H}, \mathrm{t}, J=$ $7.2 \mathrm{~Hz}), 1.23-1.28(73 \mathrm{H}, \mathrm{m}), 1.42-1.49$ (6H, m), 1.70-1.81 (6H, m), $3.53(2 \mathrm{H}, \mathrm{s}), 3.90-$ 
$3.96(6 \mathrm{H}, \mathrm{m}), 6.46(2 \mathrm{H}, \mathrm{s})$, a carboxyl proton was not clearly detected; ${ }^{13} \mathrm{C}$ NMR (150 $\left.\mathrm{MHz}, \mathrm{CDCl}_{3}\right) \delta 14.09,22.68,26.10,26.12,29.37^{*}, 29.39 *, 29.43 *, 29.65^{*}, 29.72 *, 30.31$, $31.92,41.29,69.07,73.42,107.78,128.23,137.37,153.12,177.25$. Asterisks indicate overlapped peaks.

$2-(3,4,5-$ Trihexadecyloxyphenyl)acetyl chloride $14 \mathrm{~d}$. To a solution of $\mathbf{1 3 d}(0.514 \mathrm{~g}$, $0.600 \mathrm{mmol})$ in anhydrous THF $(20 \mathrm{~mL})$, thionyl chloride $(0.129 \mathrm{~mL}, 1.80 \mathrm{mmol})$ was added dropwise and the mixture was stirred at ambient temperature for $1 \mathrm{~h}$. The solvent and thionyl chloride remained in the mixture was removed by distillation under reduced pressure to give crude product including $14 \mathbf{d}(0.570 \mathrm{~g})$ as a pale orange solid: ${ }^{1} \mathrm{H}$ NMR $\left(600 \mathrm{MHz}, \mathrm{CDCl}_{3}\right) \delta 0.88(9 \mathrm{H}, \mathrm{t}, J=6.9 \mathrm{~Hz}), 1.21-1.37(72 \mathrm{H}, \mathrm{m}), 1.42-1.50(6 \mathrm{H}, \mathrm{m})$, 1.70-1.82 (6H, m), 3.89-3.96 (6H, m), $4.01(2 \mathrm{H}, \mathrm{s}), 6.42(2 \mathrm{H}, \mathrm{s}) ;{ }^{13} \mathrm{C} \mathrm{NMR}(150 \mathrm{MHz}$, $\left.\mathrm{CDCl}_{3}\right) \delta 14.08,22.68,26.07,29.38^{*}, 29.40 *, 29.63^{*}, 29.67 *, 29.71 *, 30.31,31.92$, $53.20,69.13,73.39,107.95,125.93,138.06,153.35,171.81$. Asterisks indicate overlapped peaks. Compound 14d was used for synthesis of 15d without further purification.

(3,4,5-Trihexadecyloxyphenyl)methyl isocyanate $15 \mathbf{d}$. Sodium azide $(0.117 \mathrm{~g}, 1.80$ $\mathrm{mmol})$ and benzyltriethylammonium chloride $(0.205 \mathrm{~g}, 0.900 \mathrm{mmol})$ were dissolved in water $(2 \mathrm{~mL})$, and the solution was cooled using an ice bath. To this solution, crude compound $14 \mathrm{~d}(0.570 \mathrm{~g})$ in the mixture of acetone $(6 \mathrm{~mL})$ and toluene $(3 \mathrm{~mL})$ was added dropwise at the temperature between 10 and $15^{\circ} \mathrm{C}$. After addition completion, the mixture was stirred for $2 \mathrm{~h}$, and it was extracted with toluene. The combined organic layer was dried over anhydrous sodium sulfate. After filtration, the filtrate was heated at $90{ }^{\circ} \mathrm{C}$ for $1 \mathrm{~h}$, and the solvent was removed under reduced pressure to give crude product including 15d $(0.500 \mathrm{~g})$ as a pale orange solid: ${ }^{1} \mathrm{H}$ NMR $\left(600 \mathrm{MHz}, \mathrm{CDCl}_{3}\right) \delta 0.89(9 \mathrm{H}, \mathrm{t}, J=8.4$ $\mathrm{Hz}), 1.17-1.41$ (72H, m), 1.42-1.53 (6H, m), 1.66-1.85 (6H, m), 3.89-3.98 (6H, m), 4.37 $(2 \mathrm{H}, \mathrm{s}), 6.47(2 \mathrm{H}, \mathrm{s}) ;{ }^{13} \mathrm{C} \mathrm{NMR}\left(150 \mathrm{MHz}, \mathrm{CDCl}_{3}\right) \delta 14.09,21.41,22.68,26.08,29.37 *$, $29.67 *, 29.71 *$, 30.30, 31.92, 46.71, 69.13, 73.41, 105.09, 123.36, 131.94, 137.80, 153.37. Asterisks indicate overlapped peaks. Compound $\mathbf{1 5 d}$ was used for synthesis of $\mathbf{C}_{\mathbf{1 6}} \mathrm{O}-\mathbf{1}$ without further purification. 